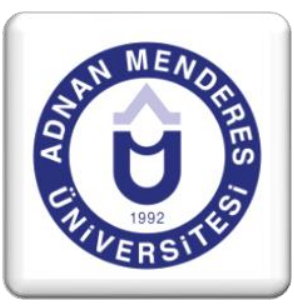

\section{Kurumsal Sosyal Sorumluluk Uygulamalarına Yönelik Algıların Müşteri Bağlılığına Etkisi: Bankacılık Sektöründe Bir Uygulama ${ }^{1}$}

\author{
Gamze YAKAR $^{2}$, Seniz ÖZHAN ${ }^{3}$
}

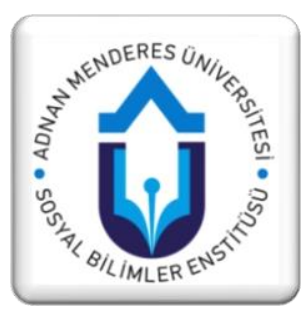

\title{
ÖZET
}

Günümüzde, sorumluluk bilincine sahip olan tüketiciler bir işletmenin ürününü satın alırken o ürünün kalite, fiyat gibi özelliklerinin yanında ürünü üreten işletmenin sosyal konularda ne derece etkin olduğu gibi kriterleri de göz önünde bulundurarak seçimlerini yapmaktadır. Bu da, işletmeleri kurumsal sosyal sorumluluk çalışmalarına iten en önemli etkenlerden birini oluşturmaktadır. $\mathrm{Bu}$ çalışma, tüketicilerin işletmelerin kurumsal sosyal sorumluluklarına yönelik algılarının işletme ve ürünlerine bağlılıklarını etkileyip etkilemediğini irdelemesi yönünden önem arz etmektedir. Araştırmada, tüketicilerin kurumsal sosyal sorumluluk uygulamalarına yönelik algılarının bağlılıklarına etkisinin ölçülmesi amaçlanmıştır. Araştırma, bankacılık sektöründe faaliyet gösteren ve Borsa İstanbul (BIST) Sürdürülebilirlik Endeksi Kasım 2015-Ekim 2016 Dönemi değerlemeye tabi şirketler listesinde yer alan Garanti bankası, Akbank ve Yapı Kredi bankası müşterilerine yönelik olarak yapılmıştır. Araştırma için gerekli veriler anket formu kullanılarak 25/04/2016-29/04/2016 tarihleri arasında ilgili bankalarda işlem yapmak üzere bekleyen müşterilerden yüz yüze görüşme yöntemi ile toplanmıştır. 450 müşterinin cevapları sonucunda elde edilen veriler öncelikle SPSS 17 paket programı kullanılarak analiz edilmiş ve yorumlanmıştır. Yapılan Faktör Analizi sonucunda veriler ticari sorumluluk, etik ve sosyal sorumluluk ve bağl1lık adlı üç faktör altında toplanmıştır. Korelasyon analizi sonucunda katılımcıların kurumsal sosyal sorumluluk uygulamalarına yönelik algıları ile bağlılıkları arasında anlamlı bir ilişki tespit edilememiştir. Uygulanan Kruskal-Wallis ve Mann-Whitney U testi sonucunda ise, katılımcıların kurumsal sosyal sorumluluk uygulamalarına yönelik algılarının ve bağllıklarının cinsiyetlerine göre farklılık göstermediği, eğitim düzeyi ve hizmet aldıkları bankaya göre farklılaştığı; medeni durum ve yaşlarına göre bağlılıklarının, gelir düzeylerine göre de kurumsal sosyal sorumluluk uygulamalarına yönelik algılarının farklılık gösterdiği tespit edilmiştir.

Anahtar Kelimeler: Kurumsal Sosyal Sorumluluk, Müşteri Bağl1lığı, Bankacılık Sektörü.

\footnotetext{
${ }^{1}$ Bu çalışma 27-29 Temmuz 2017 tarihleri arasında Adnan Menderes Üniversitesi Aydın İktisat Fakültesi tarafından düzenlenen EUREFE'17 Uluslararası Kongresinde sözlü bildiri olarak sunulmuştur.

2 Öğr. Gör., Namık Kemal Üniversitesi, Çorlu Meslek Yüksek Okulu, Kooperatifçilik Programı, gyakar@nku.edu.tr

3 Öğr. Gör. Dr., Namık Kemal Üniversitesi, Çorlu Meslek Yüksek Okulu, İşletme Yönetimi Programı, serdem@nku.edu.tr
} 


\title{
The Effect of The Perception of Corporate Social Responsibility Applications on Customer Commitment: An Application In The Banking Sector
}

\begin{abstract}
At present days, the enterprises are evaluated not only by their products and services but also by their sensitivity to the society. Consumers do not think that it is enough for the enterprises to comply with the laws imposed. Moreover, they think these enterprises should give what they have gained from the society and the nature back to the society in various ways. While buying an item produced by a particular company, consumers with the good sense of responsibility make their choices considering how effective the company which produced this item is in social matters as well as this item's features such as its quality and price. This makes one of the most important factors which motivates enterprises to take part in more corporate social responsibility projects. This study carries a great role as it examines whether consumers' perception of these enterprises'attitude towards corporate social responsibility projects will affect their commitment to the company and their products. In the study, it is intended to measure the effect of customers' perception of corporate social responsibility applications over their commitment. The study is aimed at the customers of Garanti Bank, Akbank, and Yapi Kredi Bank, which are the companies operating in the banking sector and are in the list of the companies exposed to evaluation in the BIST Sustainability Index for the period between December 2015 and October 2016. The data required for the study were collected from the customers waiting to do banking operations in the mentioned banks between 25th April 2016 and 29th April 2016 through the use of questionnaire form and face-to-face interview technique. The data obtained from the answers given by 450 customers were first analyzed via SPSS 17 and then interpreted. As a result of the factor analysis carried out, the data were gathered under three factors named commercial responsibility, ethical and social responsibility, and commitment. As a result of the correlation analysis, a meaningful relationship has not been found between the participants' perception towards social responsibility applications and their loyalty. And as a the result of Kruskal-Wallis and Mann-Whitney U test, it has been found that the participants' perception of social responsibility applications and their loyalty do not differ according to their gender, and it differs according to their level of education and the bank that serves them. It has also been understood that their loyalty differs according to their marital status and age and their perception of social responsibility applications differs according to their level of income.
\end{abstract}

Keywords: Corporate Social Responsibility, Customer Commitment, Banking Sector. 


\section{Giriş}

Geçmişten bugüne kurumsal sosyal sorumluluk kavramı hükümetler, sivil toplum kuruluşları ve bireysel tüketiciler de dahil olmak üzere çeşitli unsurlar tarafindan desteklenerek, iş dünyasında kabul görmüş bir kavram haline gelmiştir (Marom, 2017: 237). Sosyal çevre içinde varlıklarını sürdüren işletmeler sadece ekonomik varlıklarıyla değil, toplumun istek ve ihtiyaçlarını karşılamaya yönelik sosyal varlıklarıyla da sorumludurlar (Yönet, 2005: 244). Günümüz toplumları için işletmelerin ürettikleri ürünler ve hizmetler kadar topluma karş1 sorumlulukları ve duyarlılıkları da önem arz etmektedir. İşletmelerin topluma karşı üstlendiği sosyal sorumluluklar, toplumun işletmeler hakkındaki düşüncelerini belirleyen faktörlerin başında gelmektedir (Bakırtaş ve Erdoğan, 2010: 98).

Uzun vadeli çıkarların kısa vadeli çıkarlara tercih edilmesini gerektiren bu anlayışta işletmelerin sosyal sorumluluklarının neleri kapsaması gerektiği ve sınırlarının belirlenmesi konusu önem arz etmektedir (Akyıldız, 2007: 19). Literatüre göre, toplum nezdinde meşruluk kazanma, marka imajı ve itibarı sağlamak, paydaşlarla daha iyi ilişkiler, çalışanların sağlığı ve güvenliği, sosyal sermaye gibi konular işletmelerin kurumsal sorumluluk alma yönündeki motivasyonlarını oluşturmaktadırlar (Magnanelli ve Izzo, 2017: 250).

$\mathrm{Bu}$ araştırma, bankacılık sektöründe faaliyet gösteren ve Borsa İstanbul (BIST) Sürdürülebilirlik Endeksi Kasım 2015-Ekim 2016 Dönemi değerlemeye tabi şirketler listesinde yer alan Garanti bankası, Akbank ve Yapı ve Kredi bankası müşterilerine yönelik olarak yapılmıştır. Çalışma, tüketicilerin işletmelerin kurumsal sosyal sorumluluklarına yönelik algılarının işletme ve ürünlerine bağlılıklarını etkileyip etkilemediğini irdelemesi yönünden önem arz etmektedir.

\section{Kurumsal Sosyal Sorumluluk (KSS) Kavramı ve Boyutları}

İşletmelerde sosyal sorumluluk kavramı, Endüstri inkılabından sonra kitlesel üretimin sonuçlarının 1950'li yıllardan itibaren daha net biçimde görülmesiyle birlikte önem kazanmaya başlamıştır (Torlak, 2007: 32). Kavramsal olarak kurumsal sosyal sorumluluk ilk kez Bowen'ın 1953 yılında yazmış olduğu "İş Adamının Sosyal Sorumlulukları" (Social Responsibilities of the Businessman) isimli kitabında yer almıştır. Bowen işadamlarının, toplumun değerleri ve hedefleriyle örtüşen faaliyetlerde bulunmaları gerekliliğini savunmuştur (Aktan ve Börü, 2007: 12).

KSS kavramı işletme sahiplerinin, ortaklarının ve yöneticilerinin işletmelerini yönetirken toplumun ihtiyaçlarını, beklentilerini ve yararını da göz önünde bulundurarak hareket etmesi ve işletmeyi yönetmesi şeklinde tanımlanabilir (Köker, 2013: 143). Kavramın gelişiminde önemli bir yere sahip olan Carroll sosyal sorumluluğu dört boyutta incelemiş ve işletmelerin sosyal sorumluluğunu, "Belirli bir zamanda toplumun şirketlerden beklediği ekonomik, yasal, etik ve gönüllü olarak yapması gereken sorumluluk faaliyetlerinin toplamını kapsar" şeklinde tanımlamıştır (Carroll, 1979: 500).

Ekonomik Sorumluluklar: Ekonomik sorumluluklar kurumsal sosyal sorumluluğun ilk boyutunu oluşturmakta ve hissedarların kazançlarını artırmak, işletmenin maksimum kârlılığını sağlamak, rekabetçi pozisyonu sürdürmek ve işletme verimliliğini sağlayarak işletmenin devamlılığını sağlamak ile ilgilidir (Carroll, 1991: 40). Ekonomik sorumluluklar işletmelerin en önemli varlık nedenleri olarak kabul edilebilir. Aksi halde işletmenin hayatını sürdürmesi mümkün değildir. Klasik yaklaşımda da ekonomik sorumluluklar işletmenin asıl ve en önemli sorumluluğu olarak kabul edilir (Torlak, 2007: 61). 
Yasal Sorumluluklar: İşletmelerin ekonomik misyonlarını yerine getirirken yasal düzenlemelere uyması beklenmektedir (Akdemir, 2008: 27). İşletmelerin yasal sorumlulukları, yasalara uymak, merkezi ve yerel düzenlemelere uymak, yasalara saygıll bir vatandaş olmak ve işletmelerin yasal yükümlülüklerini yerine getirmesi gibi konuları kapsamaktadır (Carroll, 1991: 40).

Etik Sorumluluklar: Yasalarda yer almamasına rağmen toplumun işletmelerden beklediği doğru ve adil davranışları içerir (Özdemir, 2009: 59). İşletme, kendi amaç ve faaliyetlerini gerçekleştirirken topluma ve çevreye karşı oluşturabileceği olası zararları giderecek önlemler almalı ve paydaşlarının güvenini kazanabilmek için, her faaliyetinde etik performans koşullarını belirlemeli ve yönetmelidir (Ünal ve Nardalı, 2010: 8).

Gönüllü Sorumluluklar: Sosyal sorumluluk boyutlarının en üst basamağında yer alan bu sorumlulukların temelinde hayırseverlik yatmaktadır. İşletmelerin yukarıda belirtilen sorumlulukları dışında paydaşlara sağlayacağı gönüllülük esasıyla yapılan hizmetleri içermektedir (Özalp ve Tonus, 2008: 74). Bu sorumlulukların içerisinde toplumun yardımsever ve hayırsever beklentileri ile uyumlu davranmak, sanatı desteklemek, yönetici ve çalışanların kendi yerel toplulukları içindeki gönüllü ve hayırsever faaliyetlere katılmaları, özel ve kamu eğitim kurumlarına yardım sağlamak, toplumun yaşam kalitesini artıracak projelere gönüllü olarak destek vermeleri yer almaktadır (Carroll, 1991: 43).

\section{Kurumsal Sosyal Sorumluluk Uygulamalarına Yönelik Algıların Müşteri Bağlılığına Etkisi}

Küreselleşme, sınırların ortadan kalkması, bilgi çağına geçiş ve bunun neticesinde bilgiye ulaşmanın kolaylığı, teknolojide yaşanan gelişmeler gibi birçok faktör tüketici algılarında değişime sebebiyet vermiştir. $\mathrm{Bu}$ değişim ise, tüketicilerin satın alma davranışlarını etkilemiştir. Günümüzde tüketiciler artık bir ürün veya hizmeti satın alırken ürünün fonksiyonel özellikleri, fiyat, kalite, marka gibi unsurların yanında ürün veya hizmeti pazara sunan işletmenin sosyal sorumluluk faaliyetlerini ve etik itibarlarını da dikkate almaktadır.

İşletmelerin faaliyetlerini sürdürmeleri ve düzenli gelir elde etmeleri için sürekli müşterilere ihtiyaç duymaları dünyada müşteri bağlılı̆gı oluşturma yönlü pazarlamaya doğru bir yönelimi ortaya çıkarmıştır (Barutçu, 2007: 352). Literatürdeki pek çok araştırma da sosyal sorumluluk faaliyetlerinin müşteri bağl1lığ oluşturmada etkili olduğunu ortaya koymuştur. Müşteri bağlılığı, müşterinin ihtiyaçlarını gidermek için aynı mal ve hizmetten ya da aynı işletmeden tekrar satın alma eğilimi şeklinde tanımlanabilir (Özgüven, 2013: 30).

İşletmeler toplumdan ve doğadan elde ettikleri kazanımların karşılığını bir şekilde topluma ve doğaya geri vermelidirler. Bu rekabet düzeni içerisinde işletmelerin ayakta kalabilmesi ve varlıklarını sürdürebilmeleri için kamuoyunun güvenini sağlamak ve onayını almak durumundadırlar. $\mathrm{Bu}$ aşamada işletmelerin sosyal sorumluluk uygulamalarının tüketici nezdinde nasıl bir konumda yer edindiğini belirlemek işletmelerin faaliyetlerine de etki edecektir. Bu sebeple tüketici tutum ve davranışlarının çeşitli araştırmalarla ölçülmesi ve değerlendirilmesi hem toplum için hem de işletmeler için büyük önem arz etmektedir.

\section{Yöntem}

$\mathrm{Bu}$ araştırmanın amacı, tüketicilerin kurumsal sosyal sorumluluk uygulamalarına yönelik algıları ile bağlılıkları arasındaki ilişkinin incelenmesidir. Araştırma için gerekli olan veriler anket yöntemi kullanılarak elde edilmiştir. Anket formunda üç grup soru yer almıştır. Birinci 
grup sorular cevaplayıcıların demografik özelliklerini, ikinci gruptaki sorular araştırmanın bağımsız değişkeni olan kurumsal sosyal sorumluluk boyutlarını (ticari sorumluluklar, etik ve sosyal sorumluluklar) ölçmek için hazırlanmıştır. Üçüncü gruptaki sorular ise, bağımlı değişken olan müşteri bağlılığını ölçmek üzere hazırlanmıştır.

Anket formunun hazırlanmasında ticari sorumluluk ile etik ve sosyal sorumluluk boyutlarını ölçmeye yönelik 12 ifade Singh vd. (2008)'den, müşteri bağlılığını ölçmeye yönelik ise, Garbarino ve Johnsson (1999)'dan 4 ifadeden yararlanılmıştır. Anket beşli likert ölçeğine (1Kesinlikle Katılmiyorum, 2-Katılmıyorum, 3-Fikrim Yok, 4-Katılıyorum, 5-Kesinlikle Katılıyorum) göre hazırlanmış sorulardan oluşturulmuştur. Araştırmada elde edilen veriler SPSS 17 programı kullanılarak analiz edilmiştir.

Araştırma, bankacılık sektöründe faaliyet gösteren ve Borsa İstanbul (BIST) Sürdürülebilirlik Endeksi Kasım 2015-Ekim 2016 Dönemi değerlemeye tabi şirketler listesinde yer alan Garanti bankası, Akbank ve Yap1 ve Kredi bankası müşterilerine yönelik olarak yapılmıştır. Araştırma için gerekli verilerin toplanması için, anket formu aracılığılla25/04/2016-29/04/2016 tarihleri arasında ilgili bankalarda işlem yapmak üzere bekleyen müşterilerle yüz yüze görüşmeler yapılmış, 450 anket formu elde edilmiş ve analiz edilmiştir. Araştırmada geliştirilen model Şekil 1'de gösterilmiştir.

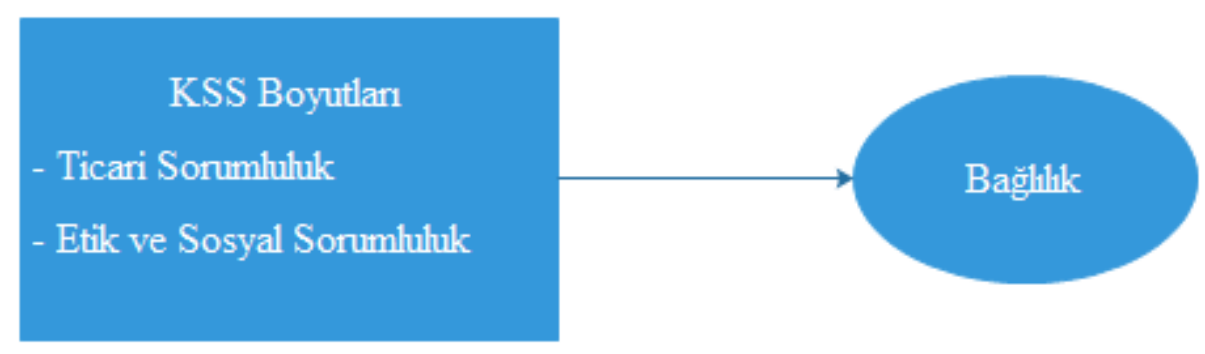

Şekil 1. Araştırma Modeli

Araştırmanın hipotezleri ise, aşağıda yer almaktadır:

$\mathrm{H}_{1}$ : Katılımcıların ticari sorumluluklara yönelik algıları ile bağlılıkları arasında anlamlı bir ilişki vardır.

$\mathrm{H}_{2}$ :Katılımcıların etik ve sosyal sorumluluklara yönelik algıları ile bağl1lıkları arasında anlamlı bir ilişki vardır.

$\mathrm{H}_{3}$ : Katılımcıların cinsiyetlerine göre kurumsal sosyal sorumluluk uygulamalarına yönelik algıları arasında istatistiksel açıdan anlamlı bir farklılık vardır.

$\mathrm{H}_{4}$ : Katılımcıların cinsiyetlerine göre bağlılıkları arasında istatistiksel açıdan anlamlı bir farkl11ık vardır.

$\mathrm{H}_{5}$ : Katılımcıların yaşlarına göre kurumsal sosyal sorumluluk uygulamalarına yönelik algıları arasında istatistiksel açıdan anlamlı bir farklılık vardır.

$\mathrm{H}_{6}$ : Katılımcıların yaşlarına göre bağlılıkları arasında istatistiksel açıdan anlamlı bir farklılık vardir. 
$\mathrm{H}_{7}$ : Katılımcıların medeni durumlarına göre kurumsal sosyal sorumluluk uygulamalarına yönelik algıları arasında istatistiksel açıdan anlamlı bir farklılık vardır.

$\mathrm{H}_{8}$ : Katılımcıların medeni durumlarına göre bağlılıkları arasında istatistiksel açıdan anlamlı bir farklılık vardır.

$\mathrm{H}_{9}$ : Katılımcıların eğitim düzeylerine göre kurumsal sosyal sorumluluk uygulamalarına yönelik algıları arasında istatistiksel açıdan anlamlı bir farklılık vardır.

$\mathrm{H}_{10}$ : Katılımcıların eğitim düzeylerine göre bağlılıkları arasında istatistiksel açıdan anlamlı bir farkl11ık vardır.

$\mathrm{H}_{11}$ : Katılımciların gelir düzeylerine göre kurumsal sosyal sorumluluk uygulamalarına yönelik algıları arasında istatistiksel açıdan anlamlı bir farklılık vardır.

$\mathrm{H}_{12}$ : Katılımcıların gelir düzeylerine göre bağlılıkları arasında istatistiksel açıdan anlamlı bir farklılık vardır.

$\mathrm{H}_{13}$ : Katılımcıların hizmet aldıkları bankaya göre kurumsal sosyal sorumluluk uygulamalarına yönelik algıları arasında istatistiksel açıdan anlamlı bir farklılık vardır.

$\mathrm{H}_{14}$ : Katılımcıların hizmet aldıkları bankaya göre bağl1lıkları arasında istatistiksel açıdan anlamlı bir farklılık vardır.

\section{Bulgular}

\subsection{Demografik Yapıya İlişsin Bulgular}

Araştırma kapsamına alınan katılımcıların cinsiyet, yaş, medeni durum, eğitim düzeyi, gelir düzeyi ve hangi banka müşterisi olduklarına ilişkin veriler aşağıdaki tabloda gösterilmiştir.

Tablo 1. Katılımcıların Sosyo-Demografik Özellikleri

\begin{tabular}{l|c|c|l|c|c}
\hline Cinsiyet & $\mathbf{f}$ & $\boldsymbol{\%}$ & Aylık Gelir Düzeyi & f & \% \\
\hline Kadın & 228 & 50,7 & $0-1000 \mathrm{TL}$ & 93 & 20,7 \\
\hline Erkek & 222 & 49,3 & $1001-2000 \mathrm{TL}$ & 207 & 46,0 \\
\hline Yaş & $\mathbf{f}$ & $\boldsymbol{\%}$ & $2001-3000 \mathrm{TL}$ & 105 & 23,3 \\
\hline $18-28$ & 186 & 41,4 & $3001-4000 \mathrm{TL}$ & 37 & 8,2 \\
\hline $29-39$ & 109 & 24,2 & 4001 ve üstü & 8 & 1,8 \\
\hline $40-50$ & 99 & 22,0 & Meslek & $\mathbf{f}$ & \% \\
\hline $51-60$ & 42 & 9,3 & Kamu sektörü çalışanı & 57 & 12,7 \\
\hline $60+$ & 14 & 3,1 & Özel sektör çalışanı & 189 & 42,0 \\
\hline Medeni Durum & $\mathbf{f}$ & $\boldsymbol{\%}$ & İşçi & 64 & 14,2 \\
\hline Evli & 270 & 60,0 & Emekli & 42 & 9,3 \\
\hline Bekar & 180 & 40,0 & Serbest meslek & 9 & 2,0 \\
\hline Ĕgitim Düzeyi & $\mathbf{f}$ & $\boldsymbol{\%}$ & Ev hanımı & 23 & 5,1 \\
\hline
\end{tabular}




\begin{tabular}{l|c|c|l|c|c}
\hline İlkokul & 55 & 12,2 & Ö̆̆renci & 61 & 13,6 \\
\hline Ortaokul & 53 & 11,8 & Çalışmıyor & 5 & 1,1 \\
\hline Lise & 125 & 27,8 & Hizmet Alınan Banka & f & \% \\
\hline Ön Lisans & 143 & 31,8 & Garanti & 150 & 33,3 \\
\hline Lisans & 63 & 14,0 & Akbank & 150 & 33,3 \\
\hline Lisansüstü & 11 & 2,4 & Yapı Kredi & 150 & 33,3 \\
\hline \multicolumn{7}{l}{ Toplam Katılımc }
\end{tabular}

Tablo incelendiğinde araştırmaya katılanların \% 50,7'sinin (228 kişi) kadın, \% 49,3'ünün (222 kişi) erkek olduğu görülmektedir. Katılımcıların çoğunluğu 18-28 yaş aralığında, evli, ön lisans mezunu, 1001-2000 TL aylık gelire sahip ve özel sektör çalışanıdır.

\subsection{Faktör Yapılarının Belirlenmesi}

Faktör analizinin, değişkenlerin normal dağılıma sahip olması varsayımı vardır. Çalışmada kullanılan ankette yer alan maddeler için normal dağılım varsayımı sağlanamadığından ve literatürde bu durumlarda faktör elde edilmesinde Temel Eksen yönteminin (Principal Axis Factoring- PAF) kullanılmasının daha doğru olacağı vurgulandığından (Costello ve Osborne, 2005). PAF metodu kullanılmıştır. Elde edilen nihai faktörler, bu faktörlere ait maddelerin faktör yükleri, her bir faktörün açıkladığı varyans ve faktörlere ait güvenilirlik değerleri Tablo 2'de olduğu gibidir:

Tablo 2. Açıklayıcı Faktör Analizi Sonucunda Bulunan Faktör Yükleri ve Faktörlerin Varyansı Açıklama Yüzdeleri

\begin{tabular}{|c|c|c|c|}
\hline İfadeler & $\begin{array}{l}\text { Faktör } \\
\text { Yükleri }\end{array}$ & $\begin{array}{l}\text { Açıklanan } \\
\text { Varyans (\%) }\end{array}$ & $\begin{array}{l}\text { Cronbach } \\
\text { Alfa }\end{array}$ \\
\hline \multicolumn{4}{|l|}{ Ticari Sorumluluk } \\
\hline Ürün ve hizmetleri her zaman kalitelidir. & 0,855 & \multirow{3}{*}{17,722} & \multirow{3}{*}{0,920} \\
\hline Sürekli olarak piyasaya yenilikçi ve yeni bir ürün sürer. & 0,842 & & \\
\hline $\begin{array}{l}\text { Ürünlerinin ve hizmetlerinin özelliklerini doğru ve gerçek } \\
\text { olarak bildirir. }\end{array}$ & 0,808 & & \\
\hline \multicolumn{4}{|l|}{ Etik ve Sosyal Sorumluluk } \\
\hline Doğal çevreyi koruma konusunda duyarlılık sahibidir. & 0,834 & \multirow[b]{5}{*}{31,331} & \\
\hline Faaliyetlerini uygularken insan haklarına saygı duyar. & 0,815 & & \\
\hline Faaliyetlerini uygularken ilgili standartlara genellikle uyar. & 0,763 & & \\
\hline $\begin{array}{l}\text { Sosyal ve kültürel faaliyetlerde toplumun gelişmesini finansal } \\
\text { açıdan destekler. }\end{array}$ & 0,726 & & \\
\hline Toplum refahını arttırma konusunda duyarlılık sahibidir. & 0,695 & & \\
\hline
\end{tabular}




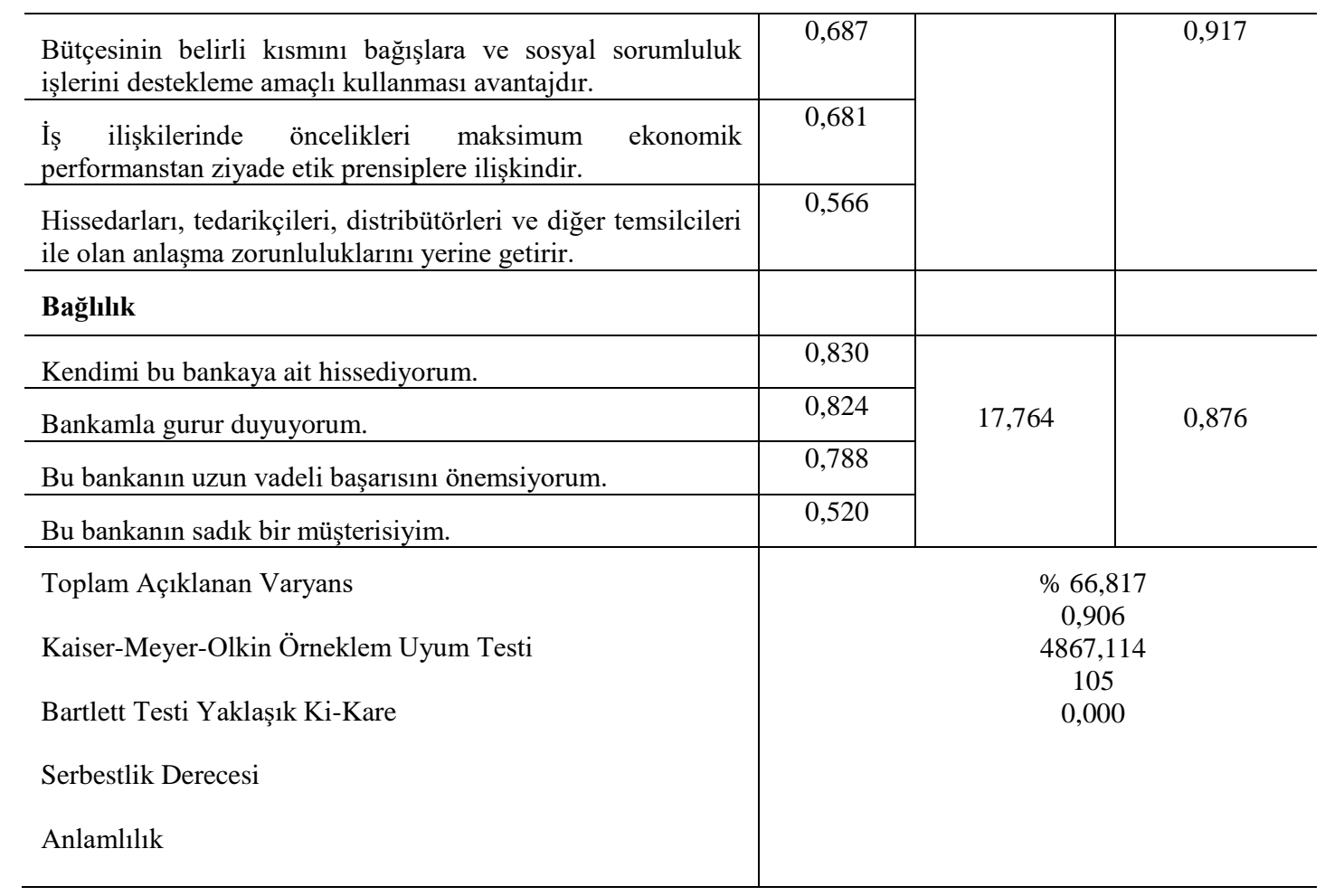

Tablo 2'de KMO değerinin 0,906ile istenen değer olan 0,50'in üzerinde olduğu görülmektedir (Hair vd., 2005). Benzer şekilde, Bartlett test değeri de anlamlı olarak bulunmuştur $(\mathrm{p}=0,000)$. Dolayısıyla verilerin faktör analizine uygun olduğu sonucuna varılabilmektedir. Analiz sonucunda, veriler üç faktör altında toplanmakta ve bu üç faktör toplam varyansın \% 66,817'sini açıklayarak, tanımlayıcı nitelikteki araştırmalarda istenen \% 60'lık değerin üzerinde bir değer sağladığı görülmektedir. Faktörlerin güvenilirlik değerleri incelendiğinde, her üç faktörün de güvenilirlik değerlerinin 0,8 ile 0,9 arasında değerler olduğu, bu nedenle yüksek güvenilirliğe sahip faktörler oldukları ifade edilebilir (Kayış, 2009: 405). Faktörlerin isimlendirilmesinde, içerdikleri değişkenler dikkate alınmıştır. Birinci faktörün altında toplanan değişkenler incelendiğinde, bu değişkenlerin bankaların ticari sorumlulukları ile ilgili oldukları görülmüş ve bu nedenle ilgili faktörün ticari sorumluluk olarak isimlendirilmesinin uygun olacağı düşünülmüştür. İkinci faktör altında toplanan değişkenler incelendiğinde ise, tümünün etik ve sosyal sorumluluklara yönelik ifadeler olduğu ve bu faktörün etik ve sosyal sorumluluk olarak isimlendirilmesine karar verilmiştir. Üçüncü faktör ise, tüketicilerin bağlılıklarına yönelik ifadelerden oluşmuş ve söz konusu faktör bağl1lık olarak adlandırılmıştır.

\subsection{Hipotezlerin Testi}

$\mathrm{H}_{1}$ ve $\mathrm{H}_{2}$ hipotezi korelasyon analizi ile test edilmiştir. Korelasyon analizi yapabilmek için değişkenlerin normal dağılım göstermeleri gerekmektedir. Yapılan Kolmogorov Simirnov testi sonucunda, verilerin normal dağılmadığ 1 tespit edildiğinden Spearman Sira Korelasyon Katsayısı kullanarak faktörler arasındaki ilişkiler ortaya konulmaya çalışılmıştır. Parametrik olmayan bir yöntem olan Spearman Sira korelasyon katsayısı dağılımın bilinmediği ya da değişkenlerin normal dağılım göstermediği durumlarda değişkenler arasındaki ilişkinin 
incelenmesi amacıyla hesaplanan bir katsayıdır (Altaş, 2013: 132). Korelasyon analizi sonuçları Tablo 3'de gösterilmiştir.

Tablo 3. Korelasyon Analizi Sonuçları

\begin{tabular}{lll}
\hline & & Bağlılık \\
& r & 0,051 \\
Ticari Sorumluluk & P & 0,284 \\
& N & 449 \\
& r & 0,012 \\
Etik ve Sosyal Sorumluluk & & \\
& P & 0,799 \\
& N & 449 \\
\hline
\end{tabular}

Yapılan korelasyon analizine göre, katılımcıların Ticari Sorumluluklara yönelik kurumsal sosyal sorumluluk uygulamalarına yönelik algıları ile bağlılıkları arasında anlamlı bir ilişki bulunmamıştır $(\mathrm{r}=0,051 ; \mathrm{p}=0,284>0,05)$. Dolayısıyla katılımcıların, ticari sorumluluklara yönelik algıları ile bağlılıkları arasında anlamlı bir ilişkinin olduğu yönünde formüle edilen $H_{l}$ hipotezi red edilmiştir.

Araştırmaya katılan katılımcıların, Etik ve Sosyal Sorumluluklara yönelik kurumsal sosyal sorumluluk uygulamalarına yönelik algıları ile bağlılıkları arasındaki ilişki incelendiğinde de anlamlı bir ilişki bulunmamıştır $(\mathrm{r}=0,012 ; \mathrm{p}=0,799>0,05)$. Bu sonuca göre katılımcıların, etik ve sosyal sorumluluklara yönelik algılarının bağlılık düzeylerini etkilemediği tespit edilmiş, dolayısıyla $\mathrm{H}_{2}$ hipotezi red edilmiştir.

$\mathrm{H}_{3}, \mathrm{H}_{4}, \mathrm{H}_{7}$ ve $\mathrm{H}_{8}$ hipotezlerini test etmek için Mann-Whitney $\mathrm{U}$ testi uygulanmıştır. Analiz sonuçları Tablo 4'de gösterilmiştir.

Tablo 4. Cinsiyetlerine ve Medeni Durumlarına Göre Mann-Whitney U Testi Sonuçları

\begin{tabular}{l|l|l|l|l|l}
\hline Hipotez & Boyut & $\begin{array}{l}\text { Cinsiyet- } \\
\text { Medeni } \\
\text { Durum }\end{array}$ & $\begin{array}{l}\text { Mean } \\
\text { Rank }\end{array}$ & Z değeri & $\begin{array}{l}\text { Anlamlılık } \\
\text { Düzeyi (p) }\end{array}$ \\
\hline \multirow{2}{*}{$\mathbf{H}_{3}$} & Ticari Sorumluluk & Kadın & 225,04 & & \multirow{2}{*}{$-0,254$} \\
\cline { 3 - 4 } & & Erkek & 221,94 & 0,800 \\
\cline { 3 - 5 } & Etik ve Sosyal & Kadın & 226,88 & & \\
\hline
\end{tabular}




\begin{tabular}{|c|c|c|c|c|c|}
\hline & Sorumluluk & Erkek & 220,06 & $-0,558$ & 0,577 \\
\hline \multirow[b]{2}{*}{$\mathbf{H}_{4}$} & Bağll11k & Kadın & 234,68 & \multirow[b]{2}{*}{$-1,849$} & \multirow[b]{2}{*}{0,064} \\
\hline & & Erkek & 212,11 & & \\
\hline \multirow{4}{*}{$\mathbf{H}_{7}$} & Ticari Sorumluluk & Evli & 216,16 & \multirow[b]{2}{*}{$-0,495$} & \multirow[b]{2}{*}{0,621} \\
\hline & & Bekar & 222,31 & & \\
\hline & \multirow[t]{2}{*}{$\begin{array}{lrr}\text { Etik ve } & \text { Sosyal } \\
\text { Sorumluluk } & \end{array}$} & Evli & 211,19 & \multirow{2}{*}{$-1,544$} & \multirow[b]{2}{*}{0,122} \\
\hline & & Bekar & 230,39 & & \\
\hline \multirow[t]{2}{*}{$\mathbf{H}_{8}$} & Bağll11k & Evli & 207,88 & \multirow{2}{*}{$-2,245$} & \multirow[b]{2}{*}{0,025} \\
\hline & & Bekar & 235,77 & & \\
\hline
\end{tabular}

Analiz sonuçlarına göre, cinsiyetin hiçbir boyut üzerinde istatistiksel olarak anlamlı bir etkisi olmadığı görülmüştür ( $\mathrm{p}>0,05)$. Dolayısıyla, $\mathrm{H}_{3} \mathrm{ve}_{4}$ hipotezleri reddedilmiştir.

Tablo 4 incelenmeye devam edildiğinde, medeni durumun, kurumsal sosyal sorumluluk uygulamalarına yönelik algıların üzerinde anlamlı bir etkisi olmadığı $(p>0,05)$, bağ l11ık üzerinde ise, istatistiksel olarak anlamlı bir etkisi olduğu görülmüştür $(p<0,05)$. Tablo 4'e göre, araştırmaya katılan bekar katılımcılar bağlılık boyutunda evli katılımcılardan daha yüksek skorlar işaretlemişlerdir. Evli ve bekar katılımcılar arasında bağl1lık boyutu açısından istatistiksel olarak anlamlı bir farklılık bulunmuştur $(0,025<0,05)$. Dolayısıyla $\mathrm{H}_{7}$ hipotezi reddedilirken, $\mathrm{H}_{8}$ hipotezi kabul edilmiştir. Bu sonuç, bekar katılımcıların hizmet aldıkları bankaya daha fazla bağlandıklarına işaret etmektedir.

$\mathrm{H}_{5}, \mathrm{H}_{6}, \mathrm{H}_{9}, \mathrm{H}_{10}, \mathrm{H}_{11}, \mathrm{H}_{12}, \mathrm{H}_{13}$ ve $\mathrm{H}_{14}$ hipotezlerini test etmek amaciyla Kruskal-Wallis testi yapılmıştır. Kruskal-Wallis testi sonuçları Tablo 5 'de yer almaktadır.

Tablo 5. Yaş, Eğitim, Gelir Düzeyi ve Hizmet Alınan Bankaya Göre Kruskal-Wallis Testi Sonuçları

\begin{tabular}{l|l|l|c|c|c}
\hline \multirow{2}{*}{ Hipotez } & \multicolumn{1}{|c|}{ Boyut } & \multicolumn{1}{|c|}{ Değişken } & Chi- Square & $\begin{array}{c}\text { Serbestlik } \\
\text { Derecesi (df) }\end{array}$ & $\begin{array}{c}\text { Anlamlılık } \\
\text { Düzeyi (p) }\end{array}$ \\
\hline $\mathbf{H}_{\mathbf{5}}$ & Ticari Sorumluluk & Yaş & 5,136 & 4 & 0,274 \\
\cline { 2 - 6 } & $\begin{array}{l}\text { Etik ve Sosyal } \\
\text { Sorumluluk }\end{array}$ & Yaş & 7,619 & 4 & 0,107 \\
\hline $\mathbf{H}_{\mathbf{6}}$ & Bağl1lık & Yaş & 11,045 & 4 & 0,026 \\
\hline $\mathbf{H}_{9}$ & Ticari Sorumluluk & Eğitim Düzeyi & 4,908 & 5 & 0,427 \\
\hline
\end{tabular}




\begin{tabular}{|c|c|c|c|c|c|}
\hline & $\begin{array}{l}\text { Etik ve Sosyal } \\
\text { Sorumluluk }\end{array}$ & Eğitim Düzeyi & 50,572 & 5 & 0,000 \\
\hline $\mathbf{H}_{10}$ & Bağl1lık & Eğitim Düzeyi & 14,286 & 5 & 0,014 \\
\hline \multirow[t]{2}{*}{$\mathbf{H}_{11}$} & Ticari Sorumluluk & Gelir Düzeyi & 3,256 & 4 & 0,516 \\
\hline & $\begin{array}{l}\text { Etik ve Sosyal } \\
\text { Sorumluluk }\end{array}$ & Gelir Düzeyi & 25,894 & 4 & 0,000 \\
\hline $\mathbf{H}_{12}$ & Bağlılık & Gelir Düzeyi & 5,426 & 4 & 0,246 \\
\hline \multirow[t]{2}{*}{$\mathbf{H}_{13}$} & Ticari Sorumluluk & $\begin{array}{l}\text { Hizmet Alinan } \\
\text { Banka }\end{array}$ & 18,849 & 2 & 0,000 \\
\hline & $\begin{array}{l}\text { Etik ve Sosyal } \\
\text { Sorumluluk }\end{array}$ & $\begin{array}{l}\text { Hizmet Alınan } \\
\text { Banka }\end{array}$ & 235,647 & 2 & 0,000 \\
\hline $\mathbf{H}_{14}$ & Bağlılık & $\begin{array}{l}\text { Hizmet Alinan } \\
\text { Banka }\end{array}$ & 10,388 & 2 & 0,006 \\
\hline
\end{tabular}

Yaşın etkilerini incelemek amacıyla yapılan Kruskal-Wallis testi sonucunda, yaşın yalnızca bağl1lık boyutu üzerinde istatistiksel olarak anlamlı bir etkisi olduğu görülmüştür $(p<0,05)$. Dolayısıyla, $\mathrm{H}_{5}$ hipotezi reddedilirken, $\mathrm{H}_{6}$ hipotezi kabul edilmiştir. Mean Ranks değerlerine göre; 51-60 yaş grubundaki katılımcılar diğer katılımcılara göre hizmet aldıkları bankaya daha fazla bağlanmaktadır.

Eğitim düzeyinin etkilerini incelemek amaciyla yapılan Kruskal-Wallis testi sonucunda ise, eğitim düzeyinin kurumsal sosyal sorumluluk uygulamalarına yönelik algıları ve bağlılık boyutu üzerinde istatistiksel olarak anlamlı bir etkisi olduğu görülmüştür $(p<0,05)$. Dolayısıyla, $\mathrm{H}_{9}$ ve $\mathrm{H}_{10}$ hipotezleri kabul edilmiştir. Mean Ranks değerlerine göre; lisans düzeyinde eğitim gören katılımcılar diğer katılımcılara göre etik ve sosyal sorumluluklara yönelik kurumsal sosyal sorumluluk uygulamalarını daha olumlu algılamaktadır. Lisansüstü düzeyde eğitim görmüş katılımcılar ise, hizmet aldıkları bankaya daha fazla bağlı kimselerdir.

Gelir düzeyinin etkilerini incelemek amaciyla yapılan Kruskal-Wallis testi sonucunda, gelir düzeyinin kurumsal sosyal sorumluluk uygulamalarına yönelik algıların üzerinde istatistiksel olarak anlamlı bir etkisi olduğu görülmüştür $(\mathrm{p}<0,05)$. Dolayısıyla, $\mathrm{H}_{11}$ hipotezi kabul edilirken, $\mathrm{H}_{12}$ hipotezi reddedilmiştir. Mean Ranks değerlerine göre; 0-1000 TL arasında aylık gelir düzeyine sahip olan katılımcılar diğer katılımcılara göre hizmet almış oldukları bankaların etik ve sosyal sorumluluk uygulamalarını daha olumlu algılamaktadır.

Hizmet alınan bankanın etkilerini incelemek amacıyla yapılan Kruskal-Wallis testi sonucunda, hizmet alınan bankanın tüm boyutlar üzerinde istatistiksel olarak anlamlı bir etkisi olduğu görülmüştür ( $\mathrm{p}<0,05)$. Dolayısıyla, $\mathrm{H}_{13}$ ve $\mathrm{H}_{14}$ hipotezleri kabul edilmiştir. Mean Ranks değerlerine göre; Yapı Kredi bankasından hizmet alan katılımcılar diğer katılımcılara göre hizmet almış oldukları bankaların ticari sorumluluk uygulamalarını, Akbank'dan hizmet alan katılımcılar etik ve sosyal sorumluluk uygulamalarını daha olumlu algılamakta ve Garanti Bankasından hizmet alan katılımcılar ise diğer katılımcılara göre hizmet almış oldukları bankalara daha fazla bağlıdırlar. 


\section{Sonuç}

Günümüzde işletmeler için en önemli farklılaşma araçlarından biri, kurumsal sosyal sorumluluk faaliyetleridir. Kurumsal sosyal sorumluluk uygulamalarını etkin bir şekilde gerçekleştirebilen işletmeler tüketicileri tarafından genellikle daha olumlu algılanmaktadır. $\mathrm{Bu}$ çalışmada, kurumsal sosyal sorumluluk uygulamalarına ilişkin ticari, etik ve sosyal sorumluluk boyutlarının müşteri bağlılığına etkileri tüketicilerden elde edilen veriler kullanılarak analiz edilmiştir. Bununla beraber, katılımcıların demografik özelliklerine göre KSS uygulamalarına yönelik alg1 ve bağlılıklarının farklılaşıp farklılaşmadığı da analiz edilmiştir. Var olan farklılıkları tespit etmek için Yapı Kredi, Akbank ve Garanti Bankası müşterilerinin görüşleri ele alınmıştır.

Verilerin analizi sonucunda, bankaların kurumsal sosyal sorumluluk (ticari, etik ve sosyal) uygulamalarına yönelik katılımcıların algıları ile bağlılıkları arasında anlamlı bir ilişki bulunamamıştır. Araştırma neticesinde elde edilen bu sonuç, KSS faaliyetlerinin önemini hafife indirgememelidir. Bu sonucun olası nedenlerinden biri, tüketicilerin işletmelerin ticari, etik ve sosyal faaliyetleri hakkında yeterli bilgiye sahip olmaması olabilir. Bunun yanı sıra, yapılan bir çalışmada, tüketicilerin işletmelerin olumlu mesajlarına karşı daha az duyarlılık gösterirken olumsuz uygulamalarına daha güçlü tepki verdikleri (Singh vd., 2008: 607) gözlenmiştir. Bu araştırma bulgusu da, bir diğer neden olarak sunulabilir.

Araştırma bulgularından bir diğeri de, tüketicilerin demografik özelliklerine göre KSS uygulamalarına yönelik algılarının ve bağlılıklarının farklılaştığının tespit edilmiş olmasıdır. Eğitim ve gelir düzeyi KSS uygulamalarına yönelik algılar üzerinde etkili bulunurken, medeni durum, yaş ve eğitim bağlılık üzerinde etkili bulunmuştur. Hizmet alınan banka ise, hem algılar hem de bağlılık boyutlarında farklılık yaratmıştır. Buna göre, Yap1 Kredi bankasından hizmet alan katılımcilar ticari sorumluluk uygulamalarını, Akbank'dan hizmet alanlar etik ve sosyal sorumluluk uygulamalarını daha olumlu algılamakta; Garanti Bankasından hizmet alanlar ise, hizmet aldıkları bankaya daha bağlı kimselerdir.

$\mathrm{Bu}$ araştırmanın sonuçlarına göre, KSS düşüncesine sahip işletmelerin müşteri tercih ve bağl1lı̆̆ını artırmak için daha etkin ve sürekli bir KSS iletişimine önem vermeleri öneri olarak sunulabilir. İşletmeler farklı müşterilerin farklı beklentilerine, farklı mesaj ve kanallar ile cevap vermelidirler. Bunun yanında, araştırma birtakım kısıtlara da sahiptir. Öncelikle, zaman ve maliyet kısıtlamalarından dolayı yalnızca Çorlu'daki Yapı Kredi, Akbank ve Garanti Bankası müşterilerini kapsaması, yine çalışmanın anlık araştırma şeklinde yapılması sonuçların genelleştirilebilirliğini sınırlamaktadır. Gelecekteki çalışmaların farklı bölgelerde yapılması önerilebilir. 


\section{KAYNAKÇA}

AKDEMİ, G. (2008). Tüketicilerin Kurumsal Sosyal Sorumluluk Uygulamaları Yürüten İşletmelere Karşı Tutumları Ve Gsm Sektörü Üzerine Bir Araştırma. Yayınlanmamış Yüksek Lisans Tezi. İstanbul Üniversitesi, Sosyal Bilimler Enstitüsü, İşletme Anabilim Dalı, İşletme Yönetimi ve Organizasyon Bilim Dalı, İstanbul.

AKTAN, C.C. \& BÖRÜ, D. (2007).Kurumsal Sosyal Sorumluluk: İşletmeler Ve Sosyal Sorumluluk. İçinde Coşkun Can Aktan (Ed.). Kurumsal Sosyal Sorumluluk: 11-36. İstanbul: İgiad.

AKYILDIZ, M. (2007). Sosyal Sorumluluk ve Ahlaki Yaklaşımlar Çeç̧evesinde Pazarlamanın Sürdürülebilir Gelişmedeki Rolü, Dokuz Eylül Üniversitesi Sosyal Bilimler Enstitüsü Dergisi, 9(1), 18-43.

ALTAŞ, D. (2013). İstatistiksel Analiz Teknikleri, İstanbul: Beta Yayıncılık.

BAKIRTAŞ, H. \& ERDOĞAN, B.Z. (2010). İşletmelerde Sosyal Sorumluluk: Oteller Üzerine Bir İnceleme, Eskişehir Osmangazi Üniversitesi İIBF Dergisi, 5(1), 97-110.

BARUTÇU, S. (2007). GSM Sektöründe Müşteri Bağl1lı̆̆ı: Pamukkale Üniversitesi Öğrencilerinin GSM Operatörlerine Bağlılıkları ve Bağlılıklarını Etkileyen Faktörler, Afyon Kocatepe Üniversitesi İ.I.B.F. Dergisi, 9(1), 349-372.

CARROLL, A.B. (1979). A Three-Dimensional Conceptual Map Of Corporate Performance, Academy of Management Review, 4, 497-505.

CARROLL, A.B. (1991). The Pyramid of Corporate Social Responsibility: Toward The Moral Management of Organisational Stakeholders, Business Horisons, 34(4), 3948.

COSTEllo, A. B. \& OSBORNE, J. W. (2005). Best Practices in Exploratory Factor Analysis: Four Recommendations for Getting the Most FromYour Analysis, Practical Assessment Research \& Evaluation, 10(7), 1-9.

GARBORINA, E. \& JOHNSON, M.S. (1999). The Different Roles of Satisfaction, Trust, and Commitment in Customer Relationships, Journal of Marketing, 63, 70-87.

HAIR, C. F, ANDERSON, R. E., TATHAM, R. L. \& BLACK, V. C. (2005). Multivariate Data Analaysis, (6th edition). New Jersey: Printence Hall.

KAYIŞ, A. (2009). Güvenilirlik Analizi. İçinde Şeref Kalaycı (Ed.). Spss Uygulamalı Çok Değişkenli İstatistik Teknikleri: 403-424. 4. Baskı. Ankara: Asil Yayın Dağıtım.

KÖKER, N. E. (2013). Sosyal Sorumluluk Faaliyetlerinin Kurumların Dış Çevreleri Tarafından Algılanması: Ampirik Bir Araştırma, Yakın Doğu Üniversitesi Sosyal Bilimler Dergisi, 6(1), 140-168.

MAGNANELLI, B.S. \& IZZO, M.F. (2017). Corporate Social Performance and Cost of Debt: the relationship, Social Responsibility Journal, 13(2), 250-265.

MAROM, S. (2017). Social responsibility and crowdfunding businesses: a measurement development study, Social Responsibility Journal, 13(2), 235-249.

ÖZALP, İ., TONUS, H.Z. \& SARIKAYA, M. (2008). İktisadi Ve İdari Bilimler Fakültesi Örgencilerinin Kurumsal Sosyal Sorumluluk Algılamaları Üzerine Bir Araştırma, Anadolu Üniversitesi Sosyal Bilimler Dergisi, 8(1), 69-84. 
ÖZDEMIR, H. (2009). Kurumsal Sosyal Sorumluluğun Marka İmajına Etkisi, İstanbul Ticaret Üniversitesi Sosyal Bilimler Dergisi, 8(15), 57-72.

ÖZGÜVEN, N. (2013). Sosyal Pazarlama Kampanyalarına Yönelik Tutumun Müşteri Memnuniyeti ve Bağlılığına Etkisi, Ege Akademik Bakış, 13(1), 29-42.

SINGH, J., SANCHEZ, M.S. \& DEL BOSQUE, I. R. (2008). Understanding Corporate Social Responsibility And Product Perceptions In Consumer Markets: A CrossCultural Evaluation, Journal of Business Ethics, 80, 597-611.

TORLAK, Ö. (2007). Pazarlama Ahlakl: Sosyal Sorumluluklar Ekseninde Pazarlama Kararları Ve Tüketici Davranışlarının Analizi, (4. Baskı). İstanbul: Beta.

ÜNAL, A. \& NARDALI, S. (2010). İşletme Ve Pazarlama Etiğine Giriş. İçinde Ay, C., Kartal, B., \& Nardalı, S. (Ed.). Pazarlamada etik yaklaşımlar: 2-28. 1. Bask1. Ankara: Detay Yayıncilik.

YÖNET, E. (2005). Kurumsal Sosyal Sorumluluk Anlayışında Son Dönemeç: Stratejik Sorumluluk, Balıkesir Üniversitesi Sosyal Bilimler Enstitüsü Dergisi, 8(13), 239264. 